\title{
Library Journals and Academic Librarianship in Germany: A Sketch Stephen Lehmann
}

\begin{abstract}
Based partly on interviews with German library journal editors and other German librarians, this study looks at the world of German academic librarianship through the prism of German library journal publishing. The German journals differ from their American counterparts in numerous ways that reflect the differences in the structure and culture of the profession as it is practiced in two countries. An especially interesting example is the German concern with "Bibliothekspolitik," that is, questions regarding the internal politics of librarianship. The article concludes by describing a set of initiatives intended to make the German professional journals more available to American librarians.
\end{abstract}

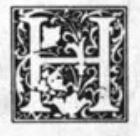

as Europe disappeared?" a bemused Swiss visitor once asked, going through a San Francisco newspaper. Indeed, one often hears the complaint that Americans are surprisingly uninformed about the world on which we have such an impact. Librarians, too, sometimes share this insular perspective: America seems big and self-contained, and if we need to communicate, well, everyone knows English. We ignore developments elsewhere, however, at our own peril. One need only consider French advances in electronic information provision, the Germans' long experience with nationally coordinated resource-sharing programs, the state-of-the art paper conservation techniques developed in Leipzig, or the English experience with a highly effective national periodicals center and document delivery program to make the point: it's a big world out there, and we would do well to know what is happening in it.

To keep informed and inform one another, academic librarians have published professional journals since the nineteenth century. The very first was the German Serapeum, founded in 1840, and its first article carried the title "University Libraries and Their Administration."1 (Some things never change.) Library journals, like those of other professions, serve a variety of purposes, both informational and scholarly. Like other forms of communication, journals also reveal themselves, the institutions they represent, and the readers they address, providing a window into the culture of the profession, exposing to the viewer its structures and its values, its

Stephen Lehmann is Humanities Bibliographer at the University of Pennsylvania, Philadelphia, Pennsylvania 19104. The author would like to thank Bas Guyt of Martinus Nijhoff International for his generosity in establishing and maintaining the grant that made this study possible; Joseph Zucca for his help in preparing the grant proposal; the following German librarians, editors, and publishers for their time and the frank, enjoyable, and very helpful discussions: W. Beck, B. Burgemeister, G. Herdt, D. Höchsmann, R. Frankenberger, K. Kempf, V. Klostermann, K.-D. Lehmann, H. Lohse, E. Mittler, K. Schreiber; Frau Bertz of the library of the Deutsches Bibliotheksinstitut in Berlin and Herr Burger, the librarian of the Fachhochschule für Bibliotheks-und Dokumentationswesen in Cologne, for their assistance; K. Schreiber, Sem C. Sutter, and Bob Walther for their suggestions in helping to prepare this article for publication. 
tensions and energies. They are "a mirror-image," as one writer put it, "of the infrastructure of librarianship of the country in which they are published." Tellingly, Mary Ann Bowman's Library and Information Science Journals and Serials: An Analytical Guide excludes all nonEnglish journals from its listings. ${ }^{3}$

To study and promote German academic library journal publishing, I interviewed the editors of the six major journals published for academic librarians during the course of a trip to Germany funded by the Martinus Nijhoff West European Specialist Study Grant in the fall of 1994. The report that follows is the result of that trip. It has a number of goals:

- To sketch a portrait of German academic librarianship through its journals;

- To encourage librarians whose responsibilities include German-related subjects (represented primarily by ACRL's 700+ member Western European Specialists Section) to cultivate a deeper and more active interest in the work of our European colleagues; and

- To offer for those who contribute to, edit, and publish U.S. library journals a description of another tradition and another practice, under the premise that a foreign perspective can provide a new and possibly useful frame of reference.

To focus specifically on the professional journals of Germany is in one sense an arbitrary choice: one could learn as much from the journals of the United Kingdom, France, Scandinavia, Italy, or Japan..$^{4-6}$ Nonetheless, it would be disingenuous to pretend that Germany is not, in this matter as in so many others, a particularly interesting and special case. It is the most populous country in Europe, with the largest book production. Its universities provided the decisive model for the development of academic research in the United States, with an impact felt to this day. Further, Germany compels a certain fascination because of its extraordinarily difficult history. You can't get away from it, even, or maybe especially, in libraries: life sto- ries, buildings, collections, all have been shaped and scarred by politics and war in a way that is difficult to imagine from American experience. In a library conference presentation, a top-level German library administrator from the former German Democratic Republic (GDR) gave poignant, characteristic expression to the mark that history has left on him and his generation: "It is the trauma of my generation ... to have gone in an almost seamless transition from one dictatorship to another, seeing, comparing, knowing and yet, as if paralyzed, heading inexorably again towards moral and political destruction.... My generation participated in this-whether as master or as servant, or as both at the same time. "7 German history is, as the expression goes, hautnah, close as your skin, and inevitably the library journals both reflect and offer reflections on the impact of Germany's wars and political upheavals on its libraries. ${ }^{8}$

\section{GERMAN LIBRARY JOURNALS}

\section{Overview}

German academic librarians publish six major journals with a national readership: ABI-Technik, Bibliothek: Forschung und Praxis, Bibliotheksdienst, Bibliotheksforum Bayern, Mitteilungsblatt des Verbandes der Bibliotheken des Landes Nordrhein-Westfalen, and Zeitschrift für Bibliothekswesen und Bibliographie. None, remarkably, is older than the present German state. Frequency of publication varies from monthly to three times a year, with approximately 100 to 200 pages per issue. Circulation figures range from less than 1,000 to close to 5,000 (compared to 13,000 for College \& Research Libraries (CERL)-a membership journal-and 2,200 for Library Quarterly).

Although the content, style, and tone of the German journals bear a clear resemblance to their American counterparts, some important distinctions remain. Germany lacks the large number of highly specialized journals that characterize U.S. academic library publishing. U.S. librarians publish journals on bibliographic instruction, on librarianship in colleges as distinct from universities, on serials librarianship, and 
numerous other subfields. This specialization is largely a function of the size of the U.S. market. In addition, according to one German, it comes from the greater willingness of American librarians to write and publish on the basis of their own day-to-day experience.

The German journals seek uniformly to expand professional horizons beyond the German experience.

The German journals all emphasize substantive content. (One of the editors of Dokumentationsdienst Bibliothekswesen $(D O B I)$, the German equivalent to $\mathrm{Li}$ brary Literature, complained that there was so little in American Libraries that it was hardly worth indexing.) The articles span the range of theoretical, historical, and practical topics familiar to readers of U.S. library journals, though the Germans seem not especially interested in the statistically based research that characterizes College \& Research Libraries. The German journals seek uniformly to expand professional horizons beyond the German experience. The flagship journal of the profession, the Zeitschrift für Bibliothekswesen und Bibliographie, for example, has initiated a series of articles that provide an overview of the field country by country; Bibliotheksdienst carries a subsection of its "Themes" feature devoted solely to contributions about libraries outside Germany, and at the back of each issue it reproduces the tables of contents of major U.S. and other foreign library journals; roughly half of the reference books and bibliographies reviewed in the Germany's new library review journal, Informationsmittel für Bibliotheken, are not in German; and the professional reading section of Bibliothek: Forschung und Praxis carries abstracts of foreign books only. Articles on every aspect of librarianship in other countries are a regular feature of the German journals, with one recently carrying a twenty-page account of an East German librarian's eighteen-library U.S. tour, "coast to coast, von N.Y. über Texas bis
Frisco." ${ }^{\prime \prime 9}$ The editors of the German journals know that the frontiers of relevant experience and knowledge do not stop at the German border.

Unlike American academic library journals such as Library Quarterly, College \& Research Libraries, and Journal of Academic Librarianship, most of the major German journals happily publish scholarship and research together with "news," covering conferences, exhibits, institutional developments, important promotions, substantial obituaries, and the like. Given the very clear, legally defined structure of ranked positions that characterizes the profession of German academic librarianship, it may be that German librarians are spared the particular ambiguities regarding status that American librarians often articulate, and therefore feel freer to publish journals that more closely reflect the profession as it is experienced by working librarians. ${ }^{10}$

Editorial practices vary among the German journals, but within a framework that is familiar to United States librarians. As is typical of many German academic journals, the editorial process is generally looser: the decision to publish or not publish an article rests in the hands of the editor, who polls editorial board members only in doubtful cases. In the U.S., by contrast, submitting all articles "blindly" to a board or outside readers for approval or rejection is standard procedure. Again, this may reflect both the greater need of U.S. academic librarians to manifest the formal requirements expected in academic publishing, to give the appearance of rigor in its standards of scholarly objectivity, as well as the less personalized (or at least less openly personalized) structures of decision making in academic librarianship on this side of the Atlantic.

Most of the editors solicit contributions, although a few say they have such a surplus of unsolicited articles that they rarely need to ask for more. Unlike their American counterparts, several of the German journals offer authors modest honoraria. As in the United States until very recently, the German journals are all edited by men, and all but one hold (or 
held) positions at the level of library director. Men, too, occupy almost all of the positions on the German editorial boards. With the exception of the two regionally based journals that are fully subsidized, the German journals pay for themselves, although the editors' home institutions may subsidize certain overhead costs.

\section{Zeitschrift für Bibliothekswesen und Bibliographie}

The $Z f B B$, as it is known, is, in the words of its editor, Klaus-Dieter Lehmann, "the classic German library journal."11 Few would disagree. Lehmann's position as the general director of the German national library, Die Deutsche Bibliothek, and his stature as the country's preeminent library administrator are an indication of the special place held by the $Z F B B$ in German librarianship. Although it is commercially published and self-supporting (with a circulation of about 1,900 , of which almost fifty are in the United States), the $Z f B B$ serves as the official journal of the two national professional associations of academic librarians. A product of the cold war, the $Z f B B$ was founded in 1954 as a West German alternative to the once distinguished but by then doctrinaire, Marxist-Leninist Zentralblatt für Bibliothekswesen $(Z f B)$ : "We needed our free journal in our free world." 12

The $Z f B B$ has a reputation for being stodgy, though its mixture of articles, reports, news features, official announcements, etc., gives each bimonthly issue a variety that is lacking in some of its U.S. counterparts. An important feature is Rolf Griebel's annual national survey of university library acquisitions budgets. The ZfBB sustained a major blow in 1993 when the editor of its highly regarded reviews of reference books and bibliographies, Klaus Schreiber, spun this feature off into a separate journal, Informationsmittel für Bibliotheken, in order to get more space. ${ }^{13}$ (In 1974 Schreiber had credited College \& Research Libraries' "Selected Reference Books" as his original model. ${ }^{14}$ ) Schreiber, known for his thoroughness and uncompromising standards, wields a famously sharp pen, and his reviews make for lively, informative reading. One senior administrator said that she regards them as a part of her Allgemeinbildung, her ongoing general education. In 1994, in a widely appreciated move to open up the $Z f B B$, it published its first "Forum"-a group of position papers on a controversial topic, in this case the proposed, governmentmandated "fusion" of the historic State Library of Saxony in Dresden with the library of the local technical university. Lehmann, fully aware of the general desire for a livelier $Z f B B$, intends to publish at least one such "Forum" a year.

\section{Der Bibliotheksdienst}

With 4,600 subscribers (including ten United States libraries), Der Bibliotheksdienst is published for librarians in both academic and public libraries, although it tends to emphasize the former. Its growth in size and stature since its inception in 1967 has paralleled closely that of its publisher, the Deutsches Bibliotheksinstitut (DBI) in Berlin. Receiving 70 percent of its funding from the states and 30 percent from the national government, the DBI is the only statesupported, national-level library organization in Germany. After unification and the elimination of the two equivalent organizations in the former GDR, it increased its staff to $180 . .^{15}$ The DBI is responsible for coordinating a large variety of nationally based projects and providing the infrastructure for a network of committees that sets guidelines for library policy at the national level. It runs an active publishing program, including the national union serials list (Zeitschriftendatenbank, or ZDB), DOBI (the previously mentioned German index to the literature of librarianship) and a large number of monographs and journals, the newest being Klaus Schreiber's Informationsmittel für Bibliotheken. The ability of the DBI to fill a need quickly was exemplified by its newsletter, Bibliotheks-Informationen OstWest, published for six months in 1990 to disseminate current information relating to unification.

Bibliotheksdienst is edited on a parttime basis by three staff members of the 
DBI. It also serves as the official journal of the Bundesvereinigung Deutscher Bibliotheksverbände, the umbrella association of German library associations. ${ }^{16}$ A very short turnaround time-as little as a month-gives it a hot-off-the-press currency. It has a bit of a rough-andready appearance to it, still bearing its origins as the newsletter it once was. Roughly half of each monthly issue is devoted to "information"-short reports of current interest, announcements and schedules of meetings, seminars, conferences, and the like. Nonetheless, each issue carries numerous articles of varying length, and it enjoys a reputation as a genuine and serious journal. American librarians responsible for acquiring German publications, for example, would not want to miss Rolf Griebel's analysis of the role of dissertations in German academic publishing. ${ }^{17}$ The articles are often on topics that have a shorter shelflife than those of the $Z f B B$, but they must be "of interest beyond the nearest church tower," in the words of editor Werner Beck. ${ }^{18}$

\section{Regional Journals}

According to the terms of the German constitution, education and culturethe bureaucratic categories to which academic and public libraries are, respectively, generally assigned-are the responsibility of the sixteen federal states and not of the national government. Since all German universities are public institutions, the funding and coordination of policies regarding academic libraries tend to be strongly centralized at the level of the state. In two states, North Rhine-Westphalia and Bavaria, academic librarians publish regional journals that reach a national readership by virtue of their reputation and the quality of their articles.

North Rhine-Westphalia, in the northwestern quadrant of Germany, is the most populous of the German states, with a population of approximately seventeen million, sixteen universities, and a system of libraries that has been traditionally well supported. It is one of the few states with its own library associa- tion, founded before World War I. The quarterly Mitteilungsblatt of the North Rhine-Westphalia Library Association, begun in 1948, is published for both academic and public librarians and has an editor for each constituency. Hartwig Lohse, the retired director of the library of the University of Bonn, has been its academic libraries editor since 1976 . Although the journal is almost entirely subsidized by local government and association funding, Lohse insists nevertheless, "We write for the whole country," and, indeed, the journal enjoys an excellent reputation nationally. ${ }^{19}$ Lohse, an engaging and outspoken man, wants the Mitteilungsblatt to be "a forum of free opinion," and he takes a characteristically iconoclastic position when he states that he is committed to publishing pretty much whatever is submitted to him. His own articles and reviews are invariably provocative and lively.

Bavaria, in the southeast, has a profound sense of its own historical identity and distinctive culture, and it carefully guards its special position within the Federal Republic. The Bavarian libraries, themselves tightly organized under a central administration in Munich, are not known as team players at the national level: the Bavarian State Library, for example, is the only major library in the country which has chosen (until this year) not to include its serial holdings in the national union list. Although it shares with the Mitteilungsblatt the distinction of being one of Germany's two "national" regional journals, the Bibliotheksforum Bayern (BFB), published three times a year, is a very different kind of publication. Whereas the Mitteilungsblatt carries the unmistakable mark of its editor, who enjoys and seeks out controversy, the editorship of the Bibliotheksforum is a responsibility assigned to the specialist for academic libraries in the office of the General Directorship of Bavarian Libraries. (The public libraries of Bavaria have their own journal, the Neue Bücherei. ${ }^{20}$ ) The fact that its new editor, Klaus Kempf, is not a Bavarian does not alter the locally focused and conservative character of the journal for 
which he is responsible. Founded in 1973 , it has remained true to its dual role as a medium for communication among Bavarian libraries and as a journal founded to represent and publicize "the community of libraries of a State of decided individuality."21 Because of the national importance of Bavaria and its libraries, the $B F B$ is by no means uninteresting to librarians elsewhere in Germany. Its annual theme issues are especially noteworthy, with highly informative articles devoted to Bavarian libraries, e.g., sci-tech collections, museum libraries, and music libraries, featuring important but little-known collections.

\section{The Bavarian libraries, themselves tightly organized under a central administration in Munich, are not known as team players at the national level.}

The library association of the state of Hamburg, publishes a less well-known but very respectable quarterly, Auskunft. Although it carries articles on a wide range of topics, the focus is definitely local. A paragraph from its first issue in 1981 gives the flavor of a certain kind of intensity characteristic of German public discourse:

The state association believes that in times in which cultural politics ["Kulturpolitik"] and thus, not least of all, libraries find themselves in the maelstrom of so-called financial exigencies, by which is meant empty state coffers-in such times it is all the more necessary to possess a mouthpiece. For one, Auskunft makes clear the immense significance of libraries within the framework of cultural politics, and it also shall offer the opportunity for libraries to express their common concerns. ${ }^{22}$

Since 1991 the library association of the state of Lower Saxony has published its regional journal, mb: Mitteilungsblatt der Bibliotheken in Niedersachsen und Sachsen-Anhalt, jointly with the "new" (eastern) state of Saxony-Anhalt as a kind of model of cooperation in a unified
Germany. Unlike its more ambitious counterparts in North Rhine-Westphalia and Bavaria, it may not appeal to a wider audience, although it serves its local readership very well.

\section{Other Commercially Published Journals}

Given the broad coverage of the two large national journals with formal associational status, it is surprising that commercial publishers find there is still room for two more, but both Bibliothek: Forschung und Praxis and ABI-Technik have secured a very distinctive niche. By curious coincidence, they share a design-their dimensions are legal-size and the text is set in double columnsthat sets them apart and gives a visual correlative to their separate status from the other journals.

Bibliothek: Forschung und Praxis, published three times a year by K. G. Saur, has a circulation of about 800 . Its price, almost twice that of any other German library publication (almost $\$ 200$ in 1995), puts it out of the range of what most U.S. libraries are willing to pay for a library journal in German, although, given its size (the equivalent of over 400 pages per issue), it gives good value per word. Its editor, Elmar Mittler, the director of the library of Göttingen University, figures prominently in the world of German academic librarianship.

The subtitle, Forschung und Praxis, translates as "research and practice," and the emphasis on extended, researchoriented articles is unique in this journal and central to its conception. (The journal was started in 1977, at a time when the Deutsche Forschungsgemeinschaft, a kind of German National Science Foundation/National Endowment for the Humanities with a major role in funding academic libraries, was promoting library-related research.) These can be up to forty pages in length, with each issue generally including the thesis (Diplomarbeit) of a recent library school graduate. Abstracts in German, English, and French precede the major articles, whose topics are broad in scope. A recent issue, for example, includes six long papers covering hypermedia systems, con- 
trol of duplicate copies in online catalogs, the social history of German public libraries, women in academic libraries from 1921 to 1945 , and public relations and libraries. In addition, the journal includes a number of short reports (current research, travel, conferences, etc.) and book reviews. Aside from the length of its articles, its other hallmark is its section of abstracted reviews of foreignlanguage books, about fifty per issue, taken largely from British and American journals. Editor Mittler stresses the importance of informing German librarians about publications from other countries, and he is justly proud of the role his journal plays in making this happen. At present he is also beginning to work toward an active cooperation with the French journal, Bulletin des Bibliothèques de France, possibly toward an exchange of articles. ${ }^{23}$

$A B I$-Technik is the only major German library journal which devotes itself to specialized subfields of librarianship, focusing solely on technology and on the physical space of the library (Bau), i.e., architecture, renovation and restoration, and other issues relating to the physical plant. This particular combination of fields came together fortuitously-they happened to be the interests of the three men who founded this quarterly in $1981 .{ }^{24}$ Visually it is the slickest of the German journals, printed on semiglossy paper, with photographs and other graphics, some even in color. Its many advertisements - the publisher, Karlheinz Holz, specializes in publications on marketing-give it an unabashedly commercialized flavor that invites a certain disapproval in German library culture. Nonetheless, no one denies its usefulness or the high quality of its articles, and its circulation of about 1,000 indicates a general popularity. The emphasis on technology from its inception, at a time when automation was just beginning to take off in Germany, positioned it well for future developments. And if there was any danger of running out of articles on the topic of the physical plant, the recent political and economic changes in Europe have stimulated a great deal of new construction as well as widespread rehabilitation of older buildings, thus giving this subject new and unexpected relevance.

\section{Other Journals}

In addition to the six major journals, a host of other journals are published for academic librarians. These fall into three broad groupings: technologies-focused, "alternative," and in-house journals.

Given the broad coverage of the two large national journals with formal associational status, it is surprising that commercial publishers find there is still room for two more, but both Bibliothek: Forschung und Praxis and ABI-Technik have secured a very distinctive niche.

There are a surprisingly large number of technically oriented journals in information science and new technologies. ${ }^{25}$ Of these by far the most generally useful to librarians is nfd (Nachrichten für Dokumentation), with a subtitle that is translated on the title page as "Journal for Information Theory and Work." It is issued six times a year by the German Society for Documentation. Lengthy abstracts in English accompany the articles.

Germany's "alternative" library journal, Laurentius, tends to be dismissed as a fringe publication by many librarians. The explanation of its name in each issue is indicative of its tone: "Because we are always asked-we have taken our name from that of the patron saint of librarians, who according to legend was killed in the year 258 on the order of Pope Sixtus II. It is said that he was literally roasted to death." (Lawrence is also the patron saint of the poor.) Consistent with its oppositional stance, it frequently carries articles on the former GDR, including a very personal account by Friedhilde Krause, the former director of the Deutsche Staatsbibliothek in East Berlin. ${ }^{26}$ Laurentius has been published since 1984 and is issued three times a year. ${ }^{27}$ 
Finally, German in-house library newsletters are much more substantial and ambitious than those familiar to American librarians. ${ }^{28}$ They range from thirty to sixty pages per issue, often are well enough established to have ISSNs, and some are quite polished in appearance. They are published two to four times a year and typically address a broad range of topics, e.g., how to download from an OPAC and other online systems, a study of the languages of the library's newly acquired books and the implications for cataloging, and the development of interlibrary loan at an eastern library after unification. Judging from the results, offering librarians a vehicle for thoughtful consideration of local practice and experience can stimulate an interest in communicating with one's colleagues that is quite salutary. These newsletter/journals serve an especially important function in the older, socalled two-level (zweischichtige) university libraries that are comprised of a multitude of more or less autonomous departmental libraries as well as a central library.

\section{THE IMPACT OF GERMAN UNIFICATION}

In the German context the term unification is somewhat misleading: it was not, as the word suggests, a process of two states coming together, but rather the total absorption of one by the other. Where libraries have been brought together, as with the merging of the two halves of the Staatsbibliothek in Berlin (east and west), and of the two national libraries in Frankfurt and Leipzig, a delicate balance had to be struck juggling a very complicated set of political, economic, and human factors. While the university libraries are being rebuilt, in some cases quite literally, from the foundation (including collections and restructuring of staff), much of the old East German library-related infrastructure simply disappeared-the publishers, the various centralized support and research institutions, the librarians' professional association, and most of the professional journals. ${ }^{29}$
Of the GDR's library journals the Zentralblatt für Bibliothekswesen $(\mathrm{Z} f B)$ was by far the most important and best known, having served as the profession's main journal since its founding in 1884 . When the Federal Republic absorbed the GDR in 1991, the publisher of the Zeitschrift für Bibliothekswesen und Bibliographie, Vittorio Klostermann, bought up what remained of the $Z f B$, that is, its title and subscription list-which turned out to consist largely of factory libraries that immediately went under. One issue that had to be resolved immediately was the choice of a name for the journal. Klostermann had hoped the title $Z f B B$ would be subsumed under the historic name of the

While the university libraries are being rebuilt, in some cases quite literally, from the foundation,... much of the old East German library-related infrastructure simply disappeared....

Zentralblatt..$^{30}$ Editor Lehmann says he was neutral on the subject and that the decision was made by the editorial board, which wanted to affirm the democratic traditions associated with the newer name and, further, that the whole notion of a Zentralblatt is an anachronism in the late twentieth century. The words vereinigt mit (united with) now join the two titles on the cover, with the name of the former East German journal in much smaller letters under the proud banner of the $Z f B B$. Like many aspects of unification, this trivial but characteristic example of the unambiguous and thoroughly unapologetic domination of the east by the west is seen rather differently depending on which side of the former border one happens to live. For West Germans it is kein Thema, not an issue. For the East Germans it represents the disappearance of another familiar institution that in this case goes back to the nineteenth century, though the loss here is largely symbolic. 
When asked about publishing articles by East German librarians, West German editors are unanimous in affirming their interest, although they vary in their assessment of the suitability and quality of much of the material submitted. One said, perhaps diplomatically, that there was no difference between the work of easterners and westerners, but the others (including an East German), agreed that the East Germans wrote in a way that seemed "formal and defensive," that they avoided writing about the very serious problems confronting the libraries of the former GDR, and preferred instead to publish reviews of the literature or highly specialized studies. Another said that the sensitivities on both sides were such that it was impossible for anyone to write candidly on eastwest issues. Librarians from the former east fully reciprocate this critical attitude. In addition to the very immediate feelings of grievance resulting from actual or ever-threatening loss of employment and salary inequities vis-à-vis western colleagues, they complain about everything from West German budget and accounting practices (the prohibitions from carrying funds over from one year to the next and from transferring money from one budgetary line to another) to the astonished perception that in the workplace librarians seem cowed and do little to exercise "freedom of speech," vaunted western civil liberties notwithstanding.

\section{LIBRARY JOURNALS AND "BIBLIOTHEKSPOLITIK"}

Bibliothekspolitik means, literally, library politics. It refers to the structures and relationships that influence and determine library policy (locally, regionally, and nationally) and, inevitably, access to funds made available by the government or by agencies such as the all-important Deutsche Forschungsgemeinschaft. Germans also speak of Kulturpolitik (cultural politics), Bildungspolitik/Wissenschaftspolitik/ Hochschulpolitik (educational politics), Sozialpolitik (social politics), etc. Presumably this is a vocabulary derived not only from the ability of the German lan- guage to agglutinate words but also from a general awareness of and interest in the politics of ostensibly nonpolitical spheres of public life.

In recent years Bibliothekspolitik has been the subject of a number of articles in German library journals, perhaps appearing too irregularly to constitute an ongoing "debate," but nevertheless keeping the subject of library politics alive and in general consciousness. The theme of the 1991 academic librarian conference was libraries in a unified Germany, but the presentations were on "Bibliothekspolitik... in many of its facets." ${ }^{11}$ The center of much of the controversy on the subject of library politics has been Joachim Stoltzenburg, the retired director of the University of Konstanz library, who lobs periodic bombshells in the form of articles on such topics as the domination of national policy by what he calls "the inner circle" (der innere Kreis), a small, closed network of men who determine the course of German library politics and steer decisions in such a way as to preserve their own power at the expense of more rational and disinterested policies. ${ }^{32}$ These, in turn, have stimulated reactions and responses, some direct, others oblique. ${ }^{33}$

In addition to making the "unspeakable expression" innere Kreis a fixture in the vocabulary of German librarianship, Stoltzenburg's articles have brought into open discussion a subject that is difficult by its very nature. ${ }^{34}$ Those in authority usually prefer to discuss the specific issues behind closed doors and the fundamental questions not at all; those ready to air questions of power and decision making publicly tend to be outsiders and marginal figures. Of course, the journals themselves are very much a part of the landscape of library politics, and so to raise the subject in the pages of the journals brings it uncomfortably close to home. It is very much to the credit of German librarians and their journals, as well as a positive sign for German public life and a testimony to hard-earned lessons, that they have taken on this discussion. Indeed, American librarians have something to learn here. 


\section{WHAT NEXT?}

The principle motivation for this study has been to try to open the windows of American academic librarianship more widely, here specifically to the practice of librarianship in Germany. This report represents one piece of that effort. In addition, Klaus Schreiber, the editor of the Informationsmittel für Bibliotheken, put forth the idea of a U.S. version of the IFB, so that American librarians can readily inform themselves about new and important European reference sources. A team of about thirty members of ACRL's Western European Specialist Section (WESS) and two librarians in the United Kingdom are now preparing English-language abstracts of the IFB reviews-about three hundred a year-for access through the WESS homepage, WESSWeb. ${ }^{35}$ Secondly, in order to promote the usefulness of German library journals to American librarians, the online discussion group German-E now lists their tables of contents as the journals appear. ${ }^{36} \mathrm{~A}$ third cooperative undertaking, approved early in 1995 by the editorial boards of both journals, entails the exchange of articles between $C E R L$ and the $Z f B B$. Along with other German-U.S. cooperative projects-for example, the Association of Research Libraries' German Demonstration Project, or the possible inclusion of bibliographic data from the German vendor Otto Harrassowitz in U.S. bibliographic utilitiesthese initiatives mark further progress toward an internationalization of information in a world in which political and technological barriers have fallen dramatically. Given the role that librarians hope to assume in this process, it is important, indeed necessary, that we continue to expand these frontiers in the world of our own profession.

\section{REFERENCES AND NOTES}

1. Hoffmann von Fallersleben, "Universitäts-Bibliotheken und ihre Verwaltung," Serapeum 1 (1840): 3-8.

2. H. Buck, "Bibliothekarische Fachzeitschriften," Lexikon des gesamten Buchwesens (Stuttgart: Hiersemann, 1987), 2d ed., vol. 1, 384. For a summary of German academic library journal publishing, see Gerhart Lohse, "Über das wissenschaftliche Engagement der deutschen Bibliothekare seit 1900," Zeitschrift für Bibliothekswesen und Bibliographie 31 (1984): 476-78. The literature on library journal publishing generally is considerable. See, for example, Handbuch der Bibliothekswissenschaft (Wiesbaden: Harrassowitz, 1961), vol. 2, 824-25; Richard D. Johnson, "The Journal Literature of Librarianship," Advances in Librarianship 12 (1982): 127-50; Carmel Maguire, "Good, Bad or Irrelevant: Quality, Price and Value of Library Journals," IFLA Journal 14 (1988): 318-23; Richard D. Johnson, "Current Trends in Library Journal Editing," Library Trends 36 (Spring 1988): 659-72; Dietrich H. Borchardt, "Journals for the Profession: Comments on Their Role and Function," Australian Library Journal 38 (1989): 219-26; W. Boyd Rayward, "Scholarly Publishing in Journals of Library and Information Science," Australian Library Journal 39 (1990): 127-33; and Patricia E. Stenstrom, "Library Literature," Encyclopedia of Library History (New York: Garland, 1994), 368-73.

3. Library and Information Science Journals and Serials: An Analytical Guide, comp. Mary Ann Bowman. (Westport, Conn.: Greenwood, 1985). Compare Greta Renborg, "Om att läsa utländska bibliotekstidskrifter," BBL: Biblioteksbladet 69 (1984): 238-39, which argues the usefulness of foreign library journals to Swedish librarians. On the other hand, it should be noted that all but one of the six major German journals are indexed in LISA. Two of the six are indexed in Library Literature. So it is not entirely accurate to say, as one German librarian put it, that the German journals are "left out of the loop."

4. Sheila Ritchie, "Professional Publishing in the U.K.: The Literature of Librarianship and Information Work, 1967-87," Journal of Librarianship 22 (1990): 1-40.

5. See Jack Kessler's "Wish-list, French book/library/network serials," pts. 1 and 2, FYIFrance, Jan. 15, 1993, available from kessler@well.sf.ca.us.

6. Fiona C.Harrison, "Japanese Journals in Library and Information Science: Notes on a Practical Project," Focus on International \& Comparative Librarianship 18 (1987): 32-34. 
7. Gottfried Rost, "Deutsche Einheit aus einer bibliothekarischen Sicht," Mitteilungsblatt des Verbandes der Bibliotheken des Landes Nordrhein Westfalen 43 (1993): 63. (This journal is cited subsequently in abbreviated form.)

8. In addition to the slew of historically relevant contemporary material appearing in journals during the Nazi period, after the war, and during the time of unification around 1991, the often unhappy impact of history of German academic libraries is the subject of numerous scholarly books and articles. See, for example, Hartwig Lohse's review of Die Universitätsbibliothek Freiburg im Dritten Reich in Mitteilungsblatt Nordrhein-Westfalen 33: 171-73 (1983); Dirk Thies, "Zum Erbe des Nationalsozialismus in Bibliotheken Nordrhein-Westfalens," Mitteilungsblatt Nordrhein-Westfalen 38, 3: 190-204 (1988); Hans-Gerd Happel, Das Wissenschaftliche Bibliothekswesen im Nationalsozialismus (Munich: K. G. Saur, 1989); and Bibliotheken während des Nationalsozialismus, ed. Peter Vodosek and Manfred Komorowski (Wiesbaden: Otto Harrassowitz, 1989-92). For an intelligent and forthright summation of the connections between politics and librarianship in Germany after World War II, see Hartwig Lohse's review of Die Entwicklung des Bibliothekswesens in Deutschland 19451965, Mitteilungsblatt Nordrhein-Westfalen 44 (1994): 355-61. Sem C. Sutter has written elegantly and informatively on the impact of unification on collections in "Fall of the Bibliographic Wall: Libraries and Archives in a Unified Germany," College \& Research Libraries 55 (1994): 403-10.

9. Bibliotheksdienst 28 (1994): 147, introducing Dorothea Sommer's "Bibliotheken in den USA-ein Reisebericht," 155-74.

10. Professional library positions are classified into three tiers. Those holding positions in the highest rank ("höhere Dienst") have both university and library degrees; the "gehobener Dienst" usually requires only the library degree, attained after a three-year professional training past high school; the "mittlere Dienst" comprises the clerical and lower level support positions. Librarians in each of these ranks are represented by their own professional association (see note 16 below).

11. Conversation, Frankfurt a.M., Oct. 18, 1994.

12. Clemens Köttelwesch et al., "Dank," Zeitschrift für Bibliothekswesen und Bibliographie 12 (1965): 1. On the history of the Zentralblatt see, for example, Ralf Breslau "Das 'Zentralblatt für Bibliothekswesen' in der Weimarer Republik," Zeitschrift für Bibliothekswesen und Bibliographie 37 (1990): 223-38, and especially its bibliography, note 5, 223. ZfB editors from the GDR days have recorded their memories in "Errinerungen ehemaliger Redakteure," Zentralblatt für Bibliothekswesen 100 (1986): 69-79.

13. The review section in the $Z f B B$ continues under the editorship of Erika Tröger. In 1994 Schreiber's new journal ran over nine hundred pages.

14. Zeitschrift für Bibliothekswesen und Bibliographie 21 (1974): 58.

15. Conversation with Dieter Höchsmann, Berlin, Oct. 24, 1994. Some of these are temporary positions.

16. The constituent associations of the BDB include the Deutscher Bibliotheksverband (DBV), the association of libraries; the Verein der Bibliothekare an Öffentlichen Bibliotheken (VBB), the association of public librarians; the Verein Deutscher Bibliothekare (VDB), the association of academic librarians with academic training; the Verein der Diplom-Bibliothekare an Wissenschaftlichen Bibliotheken (VdDB), the association of academic librarians with professional training; the Bundesverein der Bibliotheksassistenten/innen (BBA), the association of library assistants. Ongoing attempts to join all the librarians now in the VBB, VDB, VdDB and BBA into one organization, on the model of the disbanded East German Verband der Bibliothekare, or the ALA, have repeatedly failed, most recently at the close of 1994. The new association was to have carried the name Verein der Bibliothekarinnen und Bibliothekare Deutschlands, abbreviated VBD-"a previously undiscovered combination," as Anne Buhrfeind writes in her wry depiction of the German library associations' alphabet soup ("Ordnung muss sein," Börsenblatt für den deutschen Buchhandel, June 10, 1994, 6).

17. Rolf Griebel, "Geistes-und Sozialwissenschaftliche Verlagsdissertationen auf dem akademischen Buchmarkt in der Bundesrepublik Deutschland," Bibliotheksdienst 24 (1990): 163-73.

18. Conversation, Berlin, Oct. 25, 1994.

19. Conversation, Bonn, Oct. 20, 1994. 
20. It should be noted that German public librarians publish a number of successful journals of their own, including Buch und Bibliothek $(B u B)$, the official journal of the association of German public librarians (VBB), the German library journal with the highest circulation, and the only one with several full-time editors. Interestingly, $B u B$ has recently advertised for a part-time editorial position to cover academic libraries.

21. Bibliotheksforum Bayern 1 (1973): 3.

22. Wolfgang Scherwath, "Liebe Leser!" Auskunft 1 (1981): 5.

23. Conversation with Elmar Mittler, Göttingen, Oct. 26, 1994.

24. Conversation with Rudolf Frankenberger, Augsburg, Oct. 28, 1994.

25. Among them are Cogito: Zeitschrift für den Informationsmarkt (Darmstadt: Hoppenstedt), Datenbanken in Theorie und Praxis (Ravensburg: Steinbeis-Transferzentrum), INFO 7: Information und Dokumentation in Archiven, Mediotheken, Datenbanken (Baden-Baden: Nomos Verlagsgesellschaft), INFOdoc: Technologien für Information und Dokumentation (Baden-Baden: FBO, Fachverlag für Büro und Organisationstechnik $\mathrm{GmbH}$ ), Online: Erfolgreiches Informationsmanagement (Bergheim: Datacom Verlag), Password: Praxisberater für elektronische Informationsbeschaffung (Düsseldorf: Verlagsgruppe Handelsblatt $\mathrm{GmbH}$.) Most of these are subsidized by companies and are of widely varying quality.

26. Friedhilde Krause, "Ich habe das Beste gewollt ... " Laurentius 9 (1992): 7-24.

27. See Rainer Strzolka, "A la Recherche du temps présent oder: Das Laurentius-Syndrom," Mitteilungsblatt Nordrhein-Westfalen 35 (1985): 201-3. Laurentius is published in cooperation with the Arbeitskreis Kritische BibliothekarInnen (AKRIBIE), which also issues a newsletter, Schnitt-Stelle: Forum für aktuelle Aspekte des Informationswesens. For a description of AKRIBIE, see "Work Circle of Critical Library Workers (Arbeitskreis Kritische Bibliothekarinnen): Who We Are-What We Want," Progressive Librarian no. 8 (1993): 32-35.

28. For an overview see Joachim-Felix Leonhard and Monika Münnich, "Lokale Bibliotekszeitschriften," Bibliothek: Forschung und Praxis 5 (1981): 220-30. See also Dagmar Jank, "10 Jahre 'Bibliotheks-Informationen der Universitätsbibliothek der Freien Universität Berlin': Ein Erfahrungsbericht," Bibliotheksdienst 26 (1992): 331-36. The Harvard Library Bulletin and New York Public Library's Biblion are obviously of another order and have German counterparts in publications issued by the Staatsbibliothek in Berlin (Mitteilungen) and Die Deutsche Bibliothek (Dialog mit Bibliotheken). Some of the better known in-house journals are published by the libraries of the universities of Freiburg i.Br. (Expressum), Konstanz (Bibliothek aktuell), Tübingen (Tübinger Bibliotheksinformationen), Free University Berlin (Bibliotheks-Informationen), Bochum (Bibliothekszeitung), Bielefeld (Bibliotheksebene), Göttingen (SUB Kultur), Mainz (UBI), and Heidelberg (Theke).

29. Zentralinstitut für Bibliothekswesen and the Methodische Zentrum für wissenschaftliche Bibliotheken und Informations-und Dokumentationseinrichtungen).

30. Conversation, Frankfurt a.M., Oct. 18, 1994.

31. Ingeborg M. Soltzenburg, "Wissenschaftliche Bibliotheken im vereinten Deutschland: Bericht vom 81. Bibliothekartag in Kassel," Zeitschrift für Bibliothekswesen und Bibliographie 38 (1991): 500. Selected papers from this conference have been published as Zeitschrift für Bibliothekswesen und Bibliographie; Sonderheft 54 (1992).

32. Joachim Stoltzenburg, "Der Innere Kreis als Zentrum deutscher Bibliothekspolitik: Strukturen und Prozeduren," Bibliotheksdienst 23 (1989): 481-98. See also Stoltzenburg's "Bibliothek zwischen Tradition und Fortschritt" in Mitteilungsblatt Nordrhein-Westfalen 34 (1984): 433-56; and his "Deutsche Bibliothekspolitik zwischen Autonomie und Kooperation" in 10 Jahre Deutsches Bibliotheksinstitut-Billanz und Ausblick: Ein Kolloquium, ed. Peter Borchardt (Berlin: Deutsches Bibliotheksinstitut, 1989), 61-89.

33. See Hartwig Lohse, "Die Bibliothek in der Gegenwart: Eine Antwort an J. Stoltzenburg," Mitteilungsblatt Nordrhein-Westfalen 35 (1985): 177-81 and Ernst-Lüder Solte, "Bibliothekspolitik im Bundesstaat," Zeitschrift für Bibliothekswesen und Bibliographie 38 (1991): 425-36.

34. Hartwig Lohse's term (der unsägliche Ausdruck), Mitteilungsblatt Nordrhein-Westfalen 44 (1994): 357.

35. Edited by James M. Campbell at the University of Virginia. The URL is http: / / www.lib.virginia.edu/wess/. The URL of IFB Abstracts is http://www.library.upenn.edu/ifba.

36. To subscribe, telnet to: campbell@virginia.edu. 